\title{
GERM THEORIES OF DISEASE AND BRITISH VETERINARY MEDICINE, 1860-1890
}

\author{
by
}

\section{MICHAEL WORBOYS *}

In standard accounts of the germ theory of disease the "Golden Age of Bacteriology" dawns in Germany in 1876, with Koch showing that a specific bacillus was the essential cause of anthrax. ${ }^{1}$ Immunology, Jenner apart, is said to have begun three years later, in France, when Pasteur produced a protective vaccine by attenuating the bacillus of fowl-cholera. ${ }^{2}$ Modern microbiology began, therefore, with breakthroughs in the aetiology and control of animal diseases. This pattern extended to virology in 1898 when, again in Germany, the first pathogenic virus identified was that of foot-and-mouth disease. ${ }^{3}$

Pathological research on animal diseases was also pursued in Britain; indeed, it was in advance of continental efforts. In 1866 the Royal Commission on the Cattle Plague undertook work on the contagious agents of the disease. ${ }^{4}$ In 1874 John Simon accorded this work great significance in the development of experimental pathology, saying that it was "the first of such studies . . and the first step of discovery ...". The founding of the Brown Animal Sanatory Institution in London in 1870 would seem to confirm the advanced state of work on the pathology of animal diseases in Britain. ${ }^{6}$

* Michael Worboys, Ph.D., Department of Historical and Critical Studies, Sheffield City Polytechnic, Psalter Lane, Sheffield S11 8UZ.

This article was prepared during the tenureship of a Research Leave Grant from the Wellcome Trust, when I was a Visiting Fellow at the Wellcome Unit for the History of Medicine, University of Manchester. I would like to thank both bodies for their support and encouragement. Linda Warden, Librarian at the RVC, London, gave me valuable assistance with its Historical Collection. I would particularly like to thank John Pickstone, Steve Sturdy, and Keith Vernon for their comments on earlier drafts of this article.

${ }^{1}$ See: W. Bulloch, The history of bacteriology, London, Oxford University Press, 1938; L. A. Chevalier and M. Solotorovsky, Three centuries of microbiology, New York, Dover, 1974; and P. Collard, The development of microbiology, Cambridge University Press, 1976.

2 W. D. Foster, A history of medical bacteriology and immunology, London, Heinemann, 1970; D. J. Bibel, Milestones in immunology: a historical exploration, Madison, Wisc., Springer, 1988, pp. 19-23; A. M. Silverstein, History of immunology, San Diego, Academic Press, 1989.

${ }^{3}$ A. P. Waterson and L. Wilkinson, An introduction to the history of virology, Cambridge University Press, 1978, pp. 30-4.

${ }^{4}$ This paralleled the Auxiliary Scientific Investigations begun by the Medical Department of the Privy Council in 1865. Indeed, John Burdon Sanderson worked for both bodies and after 1866 carried out much of his work for the Medical Department at the Albert Veterinary College. Sanderson Papers, University College London, Appointment diaries, 1866-69.

${ }_{5}^{5}$ Report of the Medical Officer of the Privy Council and Local Government Board, NS, 1874, C.1068, p.5.

${ }^{6}$ G. S. Wilson, 'The Brown Animal Sanatory Institution', J. Hyg. Camb., 1979, 82: 155-76; 377-52; 501-21; 83: 171-97. 
The Brown was headed by a succession of distinguished medical scientists-John Burdon Sanderson, W. S. Greenfield, C. S. Roy and Victor Horsley-and for two decades enjoyed the services of Emanuel Klein, once called the "father of British bacteriology". ${ }^{7}$ However, these early and impressive developments were not built upon in Britain. Experimental veterinary pathology was not systematically developed, nor widely practised there during the crucial period from the mid-1870s to the early 1890 s. John M'Fadyean then led the moves to re-establish experimental work, although major veterinary research institutions were not established until after $1918 .^{8}$ This article attempts to explain how and why work on animal diseases moved from the van to the rear of experimental medical research in Britain, and to explore the veterinary reception of the main achievement of the new pathology - the germ theories of disease.

It is not proposed, however, to frame the discussion in terms of the "neglect" of experimental pathology and germ theories. The notion of neglect can be ahistorical, in that it implies there was a trajectory which veterinary medicine ought to have followed; in this case, that of reductionist experimental pathology, bacteriology, and immunology. The less deterministic stance adopted here seeks to understand how new concepts and techniques in pathology were constituted and used in the veterinary context, especially that of imported livestock diseases and epizootics. These were the main areas in which contagious and zymotic diseases were met in veterinary work. I will argue that the concerns of élite veterinarians came to focus on disease in the livestock economy, not on disease in tissues and cells or on causative microbes. Thus, as human and comparative pathology moved increasingly towards patho-physiology and to the cellular level, a new "veterinary pathology" was constructed which moved in the opposite direction, towards whole animals and populations. After 1870 veterinary theory and practice was dominated not by germ theories of disease, but by importation theories of disease. The preferred approach to the control of major livestock diseases was to keep such diseases out of the country and, when that failed, to stamp them out by restricting livestock movements and by slaughtering. Thus, in the last third of the nineteenth century, while medicine looked to science for greater understanding and control of diseases, along with professional legitimization, veterinary medicine looked to the state for the same objectives.

EPIZOOTICS AND THE VETERINARY PROFESSION, 1840-1866

Until the 1840s, Britain's island geography and trade restrictions had made its agriculture and stock-rearing less vulnerable to epizootics than those of the countries of continental Europe. ${ }^{9}$ This situation changed with the repeal of protectionist legislation and improvements in transportation times, which allowed animals carrying disease to be more readily imported. ${ }^{10}$ In 1848 outbreaks of foot-and-mouth disease

\footnotetext{
${ }^{7}$ Ibid., 83: 171-81. On Edward Emanuel Klein see: J. Path. Bact., 1925, $28: 684$.

${ }^{8}$ Ministry of Agriculture, Fisheries and Food (MAFF), Animal health: a centenary, 1865-1965, London, HMSO, 1965, pp. 311-33.

${ }^{9}$ An epizootic is the equivalent in animal populations of a human epidemic, i.e., high morbidity or mortality due to a disease not normally present in a region. G. Fleming, Animal plagues: their history, nature and prevention, London, Chapman \& Hall, 1871; T. Duckham and G. T. Brown, 'The progress of legislation against contagious diseases of livestock: parts I and II', J. R. Agric. Soc., 1893, 54: 262-86.

10 J. Gamgee, 'Epizootics', Veterinarian, 1867, 40: 537.
} 
and sheep-pox demonstrated what many had feared, namely, that free trade in livestock had brought with it free trade in livestock disease. Both diseases were seen as "foreign" and the approach taken was to stamp them out and keep them out. ${ }^{11}$ As early as 1843, the Royal Agricultural Society of England (RASE), anticipating the new dangers and the need for better understanding of cattle diseases, effected the appointment of J. B. Simonds (1810-1904) to a new Chair of Cattle Pathology at the Royal Veterinary College in London and it was he who advised the government on Orders to control the new threats. ${ }^{12}$ The proposed introduction of veterinary policing was very controversial, since it was seen by supporters of laissez-faire as a means of re-introducing protection. ${ }^{13}$ However, this episode had little political effect because the outbreaks were limited and short-lived.

Specific diseases were not named in the 1848 Order, so which diseases were covered and whether they were contagious or "foreign" or both had to be decided case by case. Throughout the 1850s and early 1860 s Simonds remained a part-time adviser to the government and continued to help monitor the threat of epizootics. His advice, based on the absence of further serious outbreaks of livestock diseases after the late 1840s, and congruent with the general anticontagionism of the mid-century, increasingly emphasized that the dangers of foreign cattle diseases had been exaggerated. In 1857 two "foreign" threats were removed, when, from an analysis of the history of foot-and-mouth and pleuropneumonia, Simonds concluded that these were native diseases which flared up under certain conditions. ${ }^{14}$ Other leading veterinarians held similar anticontagionist and anti-quarantine views. ${ }^{15}$

From the late 1850s, Simonds's expertise was complemented and more importantly rivalled by that of John Gamgee (1830-1894), a strong opponent of anticontagionism who advocated the control of livestock movements. ${ }^{16}$ In the early 1860 s Gamgee gained attention with his warnings about the dangers of epizootics and his calls, based on European experiences, for stronger veterinary policing in Britain. As both an outsider and a challenger of veterinary orthodoxy, Gamgee found few supporters and even fewer friends amongst his professional peers. However, he did find support for his views at the first International Veterinary Congress in 1864, which was hardly surprising, given that he had organized the event. Significantly, he was one of only two,

11 MAFF, op. cit., note 8 above, pp. 7-11.

12 I. Pattison, A great British veterinarian forgotten: James Beart Simonds, London, J. Allen, 1989; DNB.

${ }^{13}$ A similar controversy is discussed by S. Hoy and W. Nugent, 'Public health or protectionism?: the German-American Pork War', Bull. Hist. Med., 1989, 63: 198-224.

14 The finding was based on an analysis of tariff returns. J. B. Simonds, 'Cattle disease', J. R. Agric. Soc., 1857, 18: 201. Pattison, op. cit., note 12 above, has vigorously denied that Simonds supported the spontaneous generation of disease, arguing that he was a confirmed contagionist. But, historically, one could be both, regarding the origins and the transmission of disease as distinct.

${ }^{15}$ See the evidence to the Select Committee on Cattle Disease etc., PP, 1864 (431), VII, p. 1.

16 J. R. Fisher, 'Professor Gamgee and the farmers', Vet. Hist., NS, 1979-80, 1(2): 47-63, on p. 50. See the report that Gamgee prepared in 1862 for the Medical Department of the Privy Council on Cattle Diseases in Relation to the Supplies of Meat and Milk, PP, 1863, XXV, p. 269. Gamgee had trained in Europe and had established a new veterinary college in Edinburgh. S. A. Hall, 'John Gamgee and the Edinburgh New Veterinary College', Vet. Rec., 1965, 77: 1237-41. In 1864 he left Edinburgh, to establish another new school in London, the Albert Veterinary College, as a direct challenge to the RVC. R. D'Arcy Thompson, The remarkable Gamgees: a story of achievement, Edinburgh, Ramsey Head, 1974; Vet. Rec., 1894-95, 7: 357,365 . 
both unofficial, British participants. ${ }^{17}$ In 1864 two Bills, inspired by Gamgee, were brought before Parliament to replace the existing 1848 Orders. These measures were opposed by most agricultural and livestock interests, as well as by leading veterinarians. The strength of feeling against the measures, and Gamgee personally, was revealed in the evidence to the Select Committee on the proposals and in the Parliamentary debates. ${ }^{18}$ Predictably, the Bills were defeated. This happened almost exactly twelve months before the start of the great cattle-plague outbreak in 1865 , which saw a major turn-round in the views of agricultural interests, the government, and the veterinary élite about anticontagionism, veterinary policing, and import controls. $^{19}$

In the summer of 1865 the first government response to the confirmation that the cattle plague was present in London was to use the 1848 Orders and ask local authorities to appoint veterinarians to inspect markets, check cattle movements, and order slaughtering if necessary. ${ }^{20}$ The view of most farmers and breeders was that the disease arose spontaneously and that veterinary policing was useless and, in fact, economically more damaging than the disease itself. Most British veterinarians thought that cattle plague was contagious, but there was disagreement over whether it arose spontaneously or was imported. It was of course possible to be an anticontagionist with regard to a disease's origins and a contagionist over its spread. A central Veterinary Department was created, headed by Simonds, to collect and collate statistics on the progress of the disease and control measures. ${ }^{21}$ Within a few months hundreds of veterinary surgeons had been appointed as part-time inspectors and found themselves enjoying new powers and status. However, uncertainties over the diagnosis and treatment of the disease, from the élite right down to the irregulars, raised doubts about the competence of inspectors. Any hopes that their involvement in control and remedial measures would improve the standing of veterinarians were disappointed; controls and slaughtering were an unpopular reminder of earlier failings. ${ }^{22}$ In such circumstances, veterinarians were the first scapegoats for the whole catastrophe. ${ }^{23}$

As members of a partially-reformed profession, veterinary surgeons were a relatively easy target in 1865 . Like medical practitioners, they had from the 1830 s sought to improve their social position and incomes, although with less success. ${ }^{24}$ Like the

17 J. W. Barber Lomax, 'The First International Veterinary Congress', J. small Anim. Pract., 1963, 4(Suppl.): 17-21. The government ignored the meeting, as did the veterinary press.

${ }_{18}$ Select Committee, op. cit., note 15 above, passim; Parl. Debates, 1864, 173, cols 1740-53; ibid., 176, col. 1567; The Times, 16, 21, and 27 June 1864.

19 J. R. Fisher,'The economic effects of cattle disease in Britain and its containment', Agric. Hist., 1980, 54: $278-93$, on p. 281.

${ }^{20}$ The best source on the development of this epizootic are the books of press-cuttings made by Simonds. See: 'The Rinderpest', vols. 1-3 (Historical Collection, RVC Library, London). Also see: J. A. Hall, 'The cattle plague of 1865', Med. Hist., 1962, 6: 45-58.

${ }^{21}$ MAFF, op. cit., note 8 above, pp. 18, 24-8.

22 See: Veterinarian, 1865, 38: 627, 653, 906. Initially there was support for the pole-axe, as the disease was considered incurable, but later in 1865 more veterinarians reported cures and faith in treatment grew. Misdiagnosis and pathological confusions show that veterinarians knew very little about stock diseases.

${ }^{23}$ In the second half of 1865 The Times led a campaign critical of Britain's veterinarians. See: The Times, 19 August 1865. For a defence of veterinary actions, Veterinarian, 1865, 38: 627, 906.

${ }^{24}$ This section is based principally on I. Pattison. The British veterinary profession, 1791-1948, London, J. A. Allen, 1983. 


\section{Michael Worboys}

doctors their main route to improvement had been learning, qualification, and organization. The establishment of the Royal College of Veterinary Surgeons (RCVS) in 1844 was seen as a landmark in their campaign, yet for many years the privately-owned veterinary schools refused to grant the College any real authority. Confidence in organized veterinary medicine was not helped by bickering and rancour within the professional élite. ${ }^{25}$ Further down the ladder, it was not clear who was and who was not a veterinary surgeon. In 1862-63 it was estimated that, of the 3,451 veterinary practitioners in Britain, only 1,018 were members of the RCVS, as against 1,244 unqualified, and another 1,189 who practised in "various guises". ${ }^{26}$ Veterinary qualifications in the early 1860 s were awarded by four schools: the Royal Veterinary College (RVC), London, the Veterinary College, Glasgow, and the Dick College and the New Veterinary College, both in Edinburgh. Teaching was predominantly practical, and commonly had an apprenticeship element. Education, practice, and income were dominated by the horse, with other animals receiving relatively cursory attention.

Horses were, of course, numerous and, from thorough-bred to nag, represented a significant capital asset to their owners which repaid treatment for injuries, lameness, and more serious complaints. ${ }^{27}$ Significant veterinary income from treating pets lay in the future. For most people, except the wealthy who could afford sentiment, the repair cost of most pets was higher than their replacement cost. Veterinary surgeons saw relatively few farm or stock animals. The reasons were simple. Many farmers treated their own animals using traditional remedies, or turned to the wide range of lay healers. ${ }^{28}$ More importantly, when a beast showed any signs of disease it was expedient to slaughter early before its value fell, or the disease spread to other animals, or the animal died. The RVC constantly complained of the difficulty of meeting the syllabus on "diseases of animals of the farm", because for sound economic reasons there was effectively no diseased livestock. ${ }^{29}$

The control measures implemented in 1865 had little apparent effect on the progress of the plague; this continued to spread, and losses mounted and the public began to feel its impact in rising meat prices. The government and veterinarians had difficulties winning support for a control programme that was described as arbitrary, wasteful, barbaric, fatalistic, and decidedly "unscientific". When it became clear that its initial response had been ineffectual, the government appointed a Royal Commission to collect, weigh, and offer opinions. Its membership was predominantly p. 155.

${ }^{25}$ Sir F. Smith, The early history of veterinary literature, vol. 4, 1933, repr. London, J. A. Allen, 1976,

${ }^{26}$ Figures cited in Pattison, op. cit., note 24 above, p. 62. The profession was not practically or formally unified until the passage of the Veterinary Surgeons Bill of 1881. This defined qualifications and created a register of veterinary surgeons.

27 Veterinarian, 1867, 40: 155-6.

${ }^{28}$ Support for homoeopathy was strong amongst veterinarians and its remedies for the cattle plague were promoted widely. Veterinarian, 1865, 38: 792 and $\mathrm{Br}$. Med. J., 1865, ii: 589. A great many animal diseases were seen by veterinarians to be dietetic in origin, and specific herbs and foods were common remedies that were relatively easy to follow or copy.

${ }^{29}$ Veterinarian, 1862, 35: 276; 'Annual Report of the Royal Veterinary College for 1879' (unpublished), p. 2. 
medical, not veterinary. ${ }^{30}$ This was due in part to the greater authority of medical men, but also to the slenderness of Britain's veterinary resources as, apart from Gamgee, all of the leading metropolitan experts held posts in the Veterinary Department. The Commission reported quickly, in November, supporting stronger internal controls, although questioning the value of slaughtering. The government did not relish taking on such an interventionist programme and, while exhorting greater vigilance, left matters with local authorities, The Second Report of the Royal Commission in January 1866 made very similar recommendations, but they now supported the pole-axe and laid greater stress on the threat of imported livestock. ${ }^{31}$ In the same month, the seeming impotence of the scientific experts allowed the established Church to reaffirm the power of a higher authority when a National Prayer Day was called to ask for deliverance from the plague. ${ }^{32}$

In February 1866 the government acted more decisively. However, it was not the reasoned arguments of the expert Royal Commission which brought this change, but the disastrous experience of the cattle plague and new lobbying by agricultural interests. A national conference of agricultural and cattle-plague protection societies lobbied for stronger action, especially on the control of imports. ${ }^{33}$ This was not quite a complete about-turn by agricultural interests; rather, a shift from objecting to measures controlling the internal movement of cattle and slaughtering, to supporting calls for compensation and the control of livestock imports. ${ }^{34}$ Thus, they remained "internal" anticontagionists, while becoming "external" contagionists. Within a fortnight of the national conference a Bill introducing stronger policing measures was passed by Parliament.

Stricter veterinary policing and the acceptance of contagionism both seemed to be vindicated in the late spring of 1866 , when the official figures for reported outbreaks and deaths began to show a decline. ${ }^{35}$ How vigorously measures had actually been enforced is impossible to say, although it is worth noting that over the next half century the justification for each of the dozens of new animal-disease control Bills was the weakness of prior measures. Epidemiologists like William Farr had predicted that cattle plague would decline independently of any human agency; this did not stop veterinarians and the government claiming that it was their actions which had halted the epizootic. ${ }^{36}$ Further evidence that controls worked came from reports which showed falls in the incidence of two other cattle diseases, pleuropneumonia and foot-and-mouth disease, after the restrictions of March $1866 .{ }^{37}$ This led to the official redesignation of these diseases as epizootic, contagious, and foreign.

${ }^{30}$ First Report of the Commission appointed to inquire into the origin and nature of the cattle plague, PP, Cd. 3591, XXII, p. 1. The Commission included: Lyon Playfair; Richard Quain, MD; Bence Jones, MD;

E. A. Parkes, MD; T. Wormald, President of the Royal College of Surgeons; R. Ceeley, MRCS; and

C. Spooner, Principal of the RVC.

31 Second Report of the Commission [etc.], PP, 1866, Cd. 3600, XXII, p. 227.

32 F. M. Turner, 'Rainfall, plague and the Prince of Wales: a chapter in the conflict of religion and science',

J. Br. Stud., 1974, 13: 46-65.

33 The Times, 9 February 1866, p. $3 \mathrm{~d}$.

34 Fisher, op. cit., note 19 above, pp. 281-2.

35 Report on cattle plague in Great Britain during the years 1865, 1866 and 1867, PP, 1867-8, Cd. 4060, XVII, p. 220. Also see: Br. med. J., 1866, i: $405,444$.

36 Ibid., p. 207.

37 Veterinarian, 1867, 40: 296. 


\section{Michael Worboys}

MEDICINE AND VETERINARY MEDICINE

The medical profession was involved in the cattle-plague crisis from the outset, offering opinions on the nature, prevention, and treatment of the disease. There were differences within the profession about what to do. Some doctors argued for the application of proven medical measures and suggested, amongst other things, vaccination, isolation in "cattle sanatoria", and the use of antiseptics. ${ }^{38}$ The medical élite followed European experience and precedent in supporting controls through veterinary policing. ${ }^{39}$ The medical journals also supported government actions, although it was suggested that cattle plague, a disease like any other, would eventually succumb to medical control. ${ }^{40}$ The initial basis for this was a perceived similarity or equivalence between cattle plague and diseases like smallpox, typhoid or typhus. This raised the spectre of the disease passing to humans, a possibility soon discounted, not by any investigations, but with the realization that no ill-effects had been reported from the large number of people who must have already consumed affected meat. The attempts to find a cure were often elaborate, but they produced little of value. ${ }^{41}$ By the end of 1865 , only the homoeopaths and odd individuals, like Mr Worms of Ceylon with his much-debated mixture of "pickling onions, garlic, ground ginger and a decoction of assafoetida, stewed in eight quarts of rice-water", maintained any faith in the possibility of a cure. ${ }^{42}$

Alongside the usual procedure of taking evidence from interested parties and experts, the Royal Commission also contracted leading scientists to undertake experimental work. The results were published in a Third Report in the summer of 1866. ${ }^{43}$ John Burdon Sanderson, Lionel S. Beale, and C. Murchison investigated the pathology, aetiology, and prevention of the disease; the chemist Angus Smith worked on disinfection methods; and two veterinary surgeons tested treatments. ${ }^{44}$ None of the latter worked: once animals were infected there was an average mortality of 70 per cent. On the experimental side, both the methods and the results were seen to be highly original, and many medical men saw the Third Report as a model of advanced medical research. The British Medical Journal commented that, "in truth, we know of no disease affecting man, whose characters have been better studied ...".45

Specific findings, like Sanderson's observation that the disease could be transmitted by inoculation, were thought to be "pregnant with consequences for

\footnotetext{
38 Ibid., 1866, 39: 353. Also see: First Report, op. cit., note 30 above, p. 145. Dr Tripe said he spoke for the "unanimous opinion of the medical profession that treatment would avail". His proposed cattle sanatoria were described as 'El Dorados' in an Editorial in the Veterinarian, 1865, 38: 627, 920.

39 In 1864 John Simon called for halting cattle movement and quarantines. Select Committee, op. cit., note 15 above; and Lancet, 1865, ii: 212, 433.

${ }^{40} \mathrm{Br}$. med. J., 1865, ii: 334, 374, 611, 662; ibid., 1866, i: 405, 444.

${ }^{41}$ Investigative committees on treatments were formed in London, Edinburgh, and Norwich. See: $\mathrm{H}$. Reed, 'The Cattle-Plague', J. R. Agric. Soc., 1866, 27: 235-6.

42 Ibid., p. 261.

43 Third Report of the Commission [etc.], PP, 1866, Cd. 3656, XXII, p. 321.

44 On Burdon Sanderson (1828-1905): Proc. R. Soc., B, 1907, 79: iii-xviii; Br. med. J., 1905, ii: 1481; on Beale (1828-1906): Proc. R. Soc., B, 1907, 77: i; on Murchison: Br. med. J., 1879, i: 648-50. Some medical men hoped that the Commission might be a precedent and model for an inquiry into cholera. Lancet, 1866, ii: 12.

${ }^{45} \mathrm{Br}$. med. J., 1866, ii: 42.
} 


\section{Germ theories and British veterinary medicine}

medical doctrine". ${ }^{46}$ Beale's finding, that the contagium of cattle plague consisted of "very minute particles of matter in a living state, each capable of growing and multiplying rapidly", was also seen as highly significant. Such statements might be seen as early formulations of a germ theory of disease. However, this would be mistaken both empirically and historiographically. Sanderson's experimental findings were interpreted as having little to do with the actual transmission of the disease in pastures, trains, ships or markets. Similarly, Beale wrote that his "minute particles" were "bioplasm"-the degraded products of normal cells or tissues-a demonstration which, in his view, refuted germ theories. ${ }^{47}$

The findings on the "intimate pathology of contagion" may have been intriguing and exciting for the researchers and for medicine, but veterinarians received them coolly. George Fleming, head of the Army Veterinary Service and later editor of the Veterinary Record, commented:

Regular medical men and medical critics have lauded this third report as an immense achievement of high scientific attainments. In vain have I searched through it for a single practical fact worth the paper it is printed on and which was not known to veterinary medicine. ${ }^{48}$

This typified a wider veterinary reaction to the role of medicine during the crisis. There were numerous attacks in the veterinary journals on the way medical practitioners had pontificated on curing the cattle plague and what nonsense had been spoken. ${ }^{49}$ Veterinary surgeons were, or course, defending their professional domain. Aspersions about their learning and competence were often made by medical practitioners, who would distance themselves from the "horse doctors". In the same way, veterinary surgeons - the "horse doctors"-tried to distance themselves from farriers, cow leeches, knowledgeable farmers, and other "quacks". While medical men vigorously policed the encroachment of veterinarians into human medicine, they made many incursions the other way, for example during the cattle plague. Their investigations could be justified as research into comparative pathology; with their esoteric language and learning, medical men tended to sound more authoritative than veterinarians. The veterinary surgeons' usual defence, that their knowledge was more practical than scientific, cut little ice in the battle for authority and status. ${ }^{50}$ However, the failure of medicine during the early months of the cattle plague was seen to be as great as, if not greater than, that of the veterinary profession, a situation which veterinarians tried all they could to exploit. ${ }^{51}$

At this time veterinarians had a particularly ambivalent attitude to the medical profession. In many ways they modelled their reform campaign on that of medicine, although they recognized they were some way behind, especially regarding social

\footnotetext{
46 Op. cit., note 43 above, p. iv.

${ }^{47}$ L. S. Beale, Disease germs; their real nature, London, J. A. Churchill \& Sons, 1870; idem, Disease germs: their supposed nature, London, J. A. Churchill \& Sons, 1870.

48 Veterinarian, 1865, 38: 578.

49 Ibid., pp. 780, 792, 906; ibid., 1866, 39: 353; and ibid., 1867, 40: 563.

50 On the social position of the profession at this time see ibid., 1865, 38: 366, 385.

51 C. Hawley, 'The medical profession and the curing of the cattle plague', ibid., pp. 906-10.
} 
status. ${ }^{52}$ Both groups practised "medicine", but there were differences. Veterinarians operated in the context of hard economics - the main question was always, was the animal worth trying to save? In comparison, while economic calculations were not absent, medicine was said to be based more on sentiment, human life being sacred.

With regard to pathology, while medical practitioners tended to stress the basic identity of disease processes across the animal kingdom, veterinarians stressed the unique features of animal diseases and veterinary practice. These positions might be linked to their respective professional positions: medicine self-assured and expansive, veterinary medicine insecure and defensive. Physiology's central position in the pre-clinical curriculum and the growing stress put upon being a "scientific" practitioner meant that medical men increasingly sought to identify their enterprise with the basic sciences. The practical orientation of veterinarians put their endeavour closer to an "art" or an applied science. These differences seem to fit Johnston and Robbins's model of the cognitive and other differences between pure and applied specialities. ${ }^{53}$ They have suggested that subjects at the "purer" end of the spectrum are characterized by universalist knowledge claims and contiguity with other disciplines, whereas applied subjects produce more particularist knowledge and isolated specialities.

In practical physiology, medical students were introduced to a variety of animal types that were used to illustrate general physiological principles which were basic to all organisms or could be extrapolated to humans. ${ }^{54}$ Many of the recommended veterinary textbooks at the RVC in the 1870 s and 1880 s were animal-specific, not about veterinary medicine as such. ${ }^{55}$ Also, it was commonly observed by veterinarians that their subject was "far less exposed to the vagaries of theoretical doctrines and systems than human medicine" and was more empirical. ${ }^{56}$ However, veterinary teaching increasingly followed the reformed medical curriculum. William Williams's The principles and practice of veterinary medicine, which went through five editions between 1874 and 1888 , had no chapters devoted specifically to a single animal species. The volume was modelled on and freely quoted at length from Aitken's Science and practice of medicine. ${ }^{57}$ The adoption of the medical model was

\footnotetext{
${ }^{52}$ R. H. Dyer, 'The social position of the veterinary surgeon', ibid., p. 360. It was noted that medical men no longer used the tradesman's entrance, nor did they deal with servants. However, veterinary surgeons never went to the house, only getting as far as the stables, where they met grooms and estate workers.

${ }^{53}$ R. Johnston and D. Robbins, 'The development of specialties in industrialised science', Sociol. Rev., 1977, 25: 87-107.

${ }^{54}$ T. H. Green, Introduction to pathology and morbid anatomy, London, Renshaw, 1871; W. B. Carpenter, Manual of physiology, London, J. A. Churchill, 1846. For their pathology and physiology courses veterinary students used medical textbooks, however, these were only taught courses and were not supplemented by vivisection experiments.

55 In 1875 students used; W. Percivall, Hippo-pathology: a treatise on the disorders and lameness of the horse, London, 1834; W. Youatt on Cattle: their breeds, management and diseases, London, 1834, and W. Youatt on Sheep: their breeds, management and diseases, London, 1837. In 1888 the recommended texts were: W. Robertson's $A$ textbook of the practice of equine medicine, J. H. Steel, A treatise on diseases of the ox, J. H. Steel, $A$ treatise on diseases of the dog. Annual Reports of the RVC, 1875 and 1888.

${ }_{56}$ G. Fleming, 'Veterinary medicine', Encyclopaedia Britannica, 9th ed., London, 1888.

$57 \mathrm{~W}$. Williams, The principles and practice of veterinary medicine, Edinburgh, Maclach \& Stewart, 1874; 2nd ed. 1879; 3rd ed. 1882; 4th ed. 1884; 5th ed. 1888. This book was not recommended in London and it is unlikely to have been used at the rival Dick School in Edinburgh.
} 


\section{Germ theories and British veterinary medicine}

very evident by the 1890s in Professor McQueen's lectures in Veterinary Medicine at the RVC. ${ }^{58}$ These were organized around general categories and organ systems, drawing on particular animals and diseases as appropriate. Nonetheless, as in medicine, where the orientations of pre-clinical and clinical teaching were quite distinct, so in veterinary education, the "clinical" or practical work was inevitably species-specific and more particularist. ${ }^{59}$

The claim that medicine and veterinary medicine had divergent positions on comparative pathology may seem surprising, given the strategic importance to the development of bacteriology and immunology of diseases like rabies, anthrax, and glanders, which affect both humans and animals, not to mention smallpox and cowpox. ${ }^{60}$ However, in bacteriology the focus on germs or the "seed" of disease meant that the particular animal infected by the microbe was not that important. ${ }^{61}$ For example, in applying Koch's postulates it was crucial to find an animal model, although it did not matter which animal was used; a number would be tried until one was found where the disease process was similar to that in humans. ${ }^{62}$ Within veterinary medicine, the characteristics of the same disease in different animals were crucially important for differential diagnosis and treatment. Also, while it was true that rabies, anthrax, and glanders did affect humans, they were not common afflictions, nor, despite public alarms, were they so contagious. Ritvo has suggested some social and cultural factors behind the panics about rabies. ${ }^{63}$ Anthrax in humans was largely found as Wool-sorter's disease, a problem for a small occupational group. While glanders did gain some attention at the end of the century, it only claimed an average of three lives each year in Britain. ${ }^{64}$ The best-known example of the integration of human and animal medicine was that presented by smallpox and cowpox. That inoculation with cowpox (vaccination) could confer immunity against human smallpox was certainly an example of a disease affecting more than one species. There was uncertainty as to whether this was a case of the same disease with different characteristics in different species, or two closely-related diseases. Nonetheless, this was the only example of this phenomenon evident for over half a century; experience suggested that it was unique to this disease and these species-the exception rather than a rule.

\footnotetext{
${ }^{58}$ See the Lecture Notes of H. P. Stanley, taken from lectures by Professor McQueen, Oct. 1894 (Historical Collection, RVC Library, London.)

${ }^{59}$ On the contrast between medical science and clinical practice see: C. J. Lawrence, "“Incommunicable knowledge": science, technology and the clinical art in Britain, 1850-1914', J. contemp. Hist., 1985, 20: 503-20.

${ }^{60}$ Bulloch, op. cit., note 1 above, passim; L. Wilkinson, 'Understanding the nature of rabies: an historical perspective', in J. B. Campbell and K. M. Charlton (eds), Rabies, Boston, Kluwer Academic, 1988, pp. 13-17; idem, 'Glanders: medicine and veterinary medicine in common pursuit of a contagious disease', Med. Hist., 1981, 25: 363-84, on pp. 380-4.

${ }^{61}$ The focus in bacteriology was very much on germs, the "seeds" of disease, while medicine paid as much, if not more, attention to receptivity, predisposing factors, and immunity: i.e., the "soil". See: $\mathbf{M}$. Worboys, 'The sanatorium treatment of consumption in Britain, 1890-1914', in J. V. Pickstone (ed.), Medical innovations in historical perspective, London, Macmillan, 1991.

62 The paucity of contemporary and historical discussion of animal models is significant, but see: W. F. Bynum, “"C'est un malade": animal models and concepts of disease', J. Hist. Med., 1990, 45: 397-413; the articles in N. Rupke (ed.), Vivisection in historical perspective, London, Routledge, 1987.

${ }^{63}$ H. Ritvo, The Animal Estate, Cambridge, Mass., Harvard University Press, 1987, pp. 168-71.

64 Wilkinson, 'Glanders', note 60 above, p. 363.
} 


\section{Michael Worboys}

THE IMPORTATION THEORY OF DISEASE AND "VETERINARY PATHOLOGY"

The decline in the incidence of cattle plague and other diseases in 1866 came to be celebrated as a great landmark and achievement in the history of British veterinary science. ${ }^{65}$ Such was the indentification of epizootics and other livestock diseases with foreign cattle that the term, "importation theory" of disease, first used in 1865, gained currency. All animal-disease legislation after 1867 was based on this theory. Confidence was such that the government pushed through new Acts in 1867 and 1869, which further strengthened and extended veterinary policing. The latter was the major Contagious Diseases (Animals) Act, 1869, which applied to cattle plague, pleuropnemonia, sheep-pox, foot-and-mouth disease, sheep scab, and glanders. ${ }^{66}$

A consequence of importation theory was that epizootics were seen to be due to human agency, not to natural events. It was claimed that the predisposing causes of the recent outbreaks of epizootics were political and technological: the repeal of the "Cattle Laws" and the increasing speed of rail transport, which allowed animals still incubating disease to reach Britain. The immediate causes were the absence of effective policing at the ports. How the disease spread was clear enough: it was from animal to animal by direct or indirect contagion, the crowded conditions of cattle markets, livestock transport, and farms being especially favourable for transmission. From the perspective of importation theory a clinical or pathological view of epizootics seemed irrelevant, for the disease was not located in lesions, but in the livestock economy, herds or whole animals. It followed, too, that veterinary policing was quite unlike public health measures, having little or no interest in sanitation, water supply or nuisances. Later, in the century, Medical Officers of Health were continually shocked by the appalling sanitary condition of milksheds, dairies, cattle sheds, etc., which suggested that a sanitary mentality had not gained any hold in livestock keeping or veterinary advice.

Veterinarians were, therefore, constructing and acting upon epizootics in a manner distinct from the way doctors were working with epidemics and infections. ${ }^{67}$ Despite medicine's shift towards the contagionism associated with germ theories of disease, many in the broad range of sanitary science's concerns remained influential for decades. ${ }^{68}$ However, from the late 1860 s there was in medicine a steady growth in laboratory investigation into the nature of agents of contagion and their role in

\footnotetext{
${ }^{65}$ In the 1870 s and 1880 s some sections of the profession thought that the government and élite veterinarians were complacent. This was especially Fleming's view, and it was expressed forcefully in his Veterinary Journal. See: Vet. J., 1877, 4: 189, 551; ibid., 5: 200; ibid., 1878, 6: 186, 196. However, the assessment would later become much more favourable. See: J. McQueen, 'Veterinary Science', Encyclopaedia Britannica, 10th ed., London, 1911.

${ }^{66}$ MAFF, op. cit., note 8 above, p. 31. The title of the legislation to control venereal disease, differed from that controlling epizootics only by the omission of the word "animals" in parentheses: Contagious Diseases Act (1864, 1866, 1869); Contagious Diseases (Animals) Act (1869). The former, which permitted the registration, examination, and incarceration of prostitutes with venereal disease, involved a quite different contagious disease, but comparably legislative control. J. Walkowitz, Prostitution and Victorian society: women, class and the state, Cambridge University Press, 1980.

${ }^{67}$ M. Pelling, Cholera, fever and English medicine, 1825-1865, Oxford, Blackwell, 1976.

${ }^{68}$ L. G. Stevenson, "Science down the drain": on the hostility of certain sanitarians to animal experimentation, bacteriology and immunology', Bull. Hist. Med., 1955, 29: 1-26. Elite veterinarians shared a number of features of the "sanitarian syndrome", although this was based on a different model of disease causation, and a different philosophy of state medicine.
} 


\section{Germ theories and British veterinary medicine}

pathology, ${ }^{69}$ In fact, in the 1870 s the meaning of pathology in medicine was being expanded, taking it beyond morbid anatomy and histology-the results of diseaseto embrace physiology and biology - the processes and specific causes of disease. ${ }^{70} \mathrm{At}$ the same time élite veterinarians were also giving "pathology" a new meaning, namely, the study of the incidence of epizootics in whole populations. This was exemplified in a regular feature in The Veterinarian, 'Pathological Contributions', which reported the returns to the Privy Council's Veterinary Department of the number of animals dying of epizootics or slaughtered under legislative orders. ${ }^{71}$ In other words, "veterinary pathology" was concerned with the morbid anatomy of the British livestock economy. A healthy livestock economy was one without epizootics and other scheduled diseases.

If the ideal was no epizootic disease at all, and it was believed that this could be achieved by the more rigorous application of existing measures of control, then the new experimental pathology (i.e., patho-physiology, microscopy and, later, bacteriology, immunology, and even therapeutics) was irrelevant. Moreover, if experimental pathology was to produce alternative methods of control, say, protective inoculation or treatments, as it promised to in medicine, then this might undermine or threaten existing measures. It was admitted, however, that protective inoculation and treatments might be appropriate to Continental countries, where the presence of long land frontiers and political problems made legislative solutions difficult.

Veterinarians had a clear vested interest in the system of controls and agencies developed from 1866. The metropolitan élite comprised advisers to and administrators in a department of the Privy Council, while rank-and-file veterinary surgeons, acting as part-time inspectors, also enjoyed the authority of the state. In fact, there is clear evidence that veterinarians were indifferent to alternative approaches. In 1873, G. T. Brown, then chief government adviser, wrote disparagingly of the debates on the "minute pathology of contagion" and in favour of a "whole-animal" approach.

If a critic wished to secure attention to his remarks, he would carefully avoid such a commonplace statement as that which refers the extension of disease to the movement of infected animals and proceed to a discussion of the possibility of spontaneous origin, the prevalence of minute spores of fungi, atmospheric changes and the indirect conveyance of the poison by flies, birds and other quadrupeds . . . but still the fact remains, that the malady is kept in a state of activity mainly by means of the living creatures suffering from it. ${ }^{72}$

Simonds and Brown did undertake inoculation experiments at the RVC in the mid-1870s: these were whole-animal experiments and were monitored clinically. ${ }^{73}$ In

${ }^{69}$ In Britain, the research undertaken from 1865 on behalf of the Medical Department of the Privy Council presents the clearest example of this trend. J. L. Brand, Doctors and the State, Baltimore, Johns Hopkins University Press, 1965.

${ }^{70}$ E. R. Long, A history of pathology, New York, Dover, 1965.

71 For example see: Veterinarian, 1879, 52: 26, 92. Many issues in the 1870 s and 1880s contained this feature.

${ }_{72}$ J. R. Agric. Soc., 1873, 34: 449. On Brown (1827-1906), see the DNB.

${ }^{73}$ J. R. Agric. Soc., 1874, 35: 269, 459. 


\section{Michael Worboys}

1875 , the RASE withdrew its grant for the investigation of animal diseases from Simonds at the RVC, because he would not undertake the work they wanted. ${ }^{74}$ Indeed, it was reported that Simonds had recently said that, "there was nothing more to be discovered with reference to important diseases". ${ }^{75}$ Through the 1870 s and 1880 s the standard veterinary response to the identification of other contagious livestock diseases was simply to add them to the schedule of the 1869 Act. $^{76}$ For example, when the cattle plague arrived again in 1877, the government appointed a Select Committee on "The Cattle Plague and the Importation of Live Stock" (my emphasis). Unlike the earlier Commission, this undertook no experimental research and only invited evidence on administration and inspection.

An idiosyncratic, but nonetheless important example of the influence of importation theory can be seen in John Gamgee's career after the crisis of 1865-66. Gamgee did not, as might be expected, use the cattle plague and its consequences to further his career in veterinary medicine. In fact, after undertaking further investigations of animal disease in North America, he increasingly put his efforts into the development of refrigeration. It can be suggested that, while he may have given up veterinary medicine as such, he had not abandoned the fight against livestock diseases, but pursued it by other means. ${ }^{77}$ Gamgee believed that epizootic diseases could only be controlled by a total ban on livestock trade. Veterinary inspection and policing would, he thought, never be completely effective, always being liable to maladministration. ${ }^{78}$ With the ideal seemingly unattainable for political and economic reasons, his answer was to try to stop the trade in livestock by advancing the prospects of the trade in "deadstock" through refrigeration: what would now be termed a "technical fix". Both before and after the cattle plague, Gamgee's work revealed a conception of epizootic diseases as affecting the national livestock industry and a commitment to a practical solution at that level.

The clearest example of the alternative trajectory of "veterinary pathology" was the progressive decline in the Brown Institution's veterinary work and reputation. ${ }^{79}$ In the 1870s Sanderson and Klein, and then Sanderson's successor W. S. Greenfield, worked on a number of animal diseases. ${ }^{80}$ This was supported by the RASE, the Privy Council's Medical Department, and the Institution, but not by the Veterinary Department. In his history of the Brown, Wilson has acknowledged that "few investigations of note" on animal diseases were performed there, although he did not

${ }^{74}$ The grant was transferred to Sanderson at the Brown Institution. J. R. Agric. Soc., 1876, 37: viii.

75 Vet. J., 1876, 2: 73.

${ }^{76}$ Thus, proposals were made at various times to add rabies, swine plague (also known as pig typhoid and hog cholera), anthrax, sheep pox, glanders, and even tuberculosis.

${ }_{77}$ A similar point is suggested in Fisher, op. cit., note 16 above, pp. 57-9.

${ }^{78}$ See his evidence to the Select Committee on the Cattle Plague and the Importation of Live Stock, PP 1877 (362), IX, pp. 327-36. One intermediate solution between a total ban and free trade was to slaughter all livestock immediately upon its arrival in a country: however, Gamgee felt that this still carried a risk, especially in and around ports.

79 Wilson, op. cit., note 6 above.

${ }^{80}$ On W. S. Greenfield see the Edinb. med. J., 1919, 23: 258. Of the Brown's subsequent directors, C. S. Roy's first investigation was of pleuropneumonia: it was supported by the BMA. Roy, 'The pathological history of epizootic pleuropneumonia', Vet.J., 1880, 10: 1, 176. Victor Horsley, his successor, worked on rabies. By the time Horsley resigned in 1891 , work on animal diseases had all but ceased. 
try to explain why. The "supply side", in the form of personnel and opportunities for research, was very favourable, so it seems that the answer must lie in the absence of any demand, impetus or funding for research from the state veterinary agencies, livestock interests or veterinarians.

The three areas which Wilson highlighted as having seen noteworthy research in various ways all show the imprint of the hegemony of importation theory. First, consider Victor Horsley's work on rabies in the late $1880 \mathrm{~s} .{ }^{81}$ This subject was taken up because of deaths from hydrophobia in humans, not for veterinary reasons, although the two were obviously linked. ${ }^{82}$ Horsley successfully repeated Pasteur's experiments, but he did not go on to establish a treatment service; British citizens continued to have to travel to Paris for inoculations. What Horsley did pursue was a legislative solution through the Contagious Diseases (Animals) Act (CD(A) Act) and an amendment which required "the universal imposition of a muzzling order on dogs, coupled with the destruction of stray animals and restrictions on importation". ${ }^{83}$ In other words, a programme of stamping out and keeping out, based on importation theory.

The second area discussed by Wilson was W. S. Greenfield's investigations of anthrax, about which Tigertt has made a case for his priority over Pasteur in producing a vaccine. ${ }^{84}$ His contemporaries recognized the importance of Greenfield's work, but it was then forgotten, perhaps due to the power of what Latour sees as the Pasteurization of the history of bacteriology. ${ }^{85}$ An important difference between London and Paris was that the Pasteurians actually took the vaccine through trials and into production. Greenfield did not. He left the Brown for a medical post in Edinburgh at a crucial stage of the work and his pioneering endeavours were not followed up. Nothing more was done in Britain until 1886, when anthrax was added to the $\mathrm{CD}(\mathrm{A})$ Act. By then the previously-sceptical G. T. Brown had become interested in taking up experimental work on the vitality of the bacillus in the soil. In the event, his project was abandoned when he was unable to obtain bacteria with which to work. Undaunted, he pursued the subject by other methods, basing his work on "the facts of the history of the disease in the United Kingdom"; in other words, the population history of the disease in Britain. ${ }^{86}$

The final area of major research mentioned by Wilson was Sanderson's experiments on protective inoculation for pleuropneumonia in the 1870s. Wilson describes this work as inconclusive and as having been hampered by problems of access to infected animals. Significantly, this was in part due to the Veterinary Department's unwillingness to relax the regulations on the movement of affected

${ }^{81}$ S. Paget, Sir Victor Horsley: a study of his life and work, London, Constable, 1919.

82 J. K. Walton, 'Mad Dogs and Englishmen: the conflict over rabies in late Victorian England', Vet. Hist., 1978-9, 12: 3-26.

${ }^{83}$ Wilson, op. cit., note 6 above, p. 508.

${ }^{84}$ Ibid., pp. 346-7. W. D. Tigertt, 'Anthrax: William Smith Greenfield, MD, FRCP, Professor Superintendent, The Brown Animal Sanatory Institution', J. Hyg., 1980, 85: 415-20; W. S. Greenfield, 'Pathology, past and present', Lancet, 1881, ii: 781 .

${ }_{85}$ B. Latour, The Pasteurization of France, Cambridge, Mass., Harvard University Press, 1988, pp. 75-90.

${ }^{86}$ Annual Report of the Agricultural Department on Contagious Diseases Inspection and the Transit of Animals for 1885, PP, 1886, Cd. 4703, XIX, p. 6. 
cattle, even to allow their use in experimental research. Sanderson's work was commissioned by the RASE to test the claims of the supporters of inoculation, that it was a far more scientific, economic, and humane approach to the control of pleuropnemonia than slaughtering. Sanderson's own verdict was, that while his studies did not lend support to inoculation, neither had they disproved its value. ${ }^{87}$ Ever cautious, he called for the status quo of stamping-out and more research. Legislative control remained, but there was no further research. ${ }^{88}$ The Veterinary Department welcomed these conclusions and used them as ammunition against pro-inoculation claims, which were especially vociferous in Scotland. This lobby, led by William Rutherford, continued to promote inoculation and in the late 1870 s and early $1880 \mathrm{~s}$ this became one of the most debated and controversial questions in veterinary medicine ${ }^{89}$ Rutherford gained the support of William Williams of the New College in Edinburgh and the issue became caught up in the rivalry between the two Edinburgh veterinary colleges, with Tom Walley and John M'Fadyean of the Dick College vigorously opposing any breach in legislative control. ${ }^{90}$ Given the known preferences of the Veterinary Department, it was not surprising that control and slaughtering prevailed, but the issue would not rest.

The "Pleuro Question" again became prominent in the mid-1880s, when the government appointed a Departmental Committee to investigate inoculation. ${ }^{91}$ Again, no experimental work was commissioned, yet the Committee felt able to come down firmly against inoculation and in favour of the continuation of control through the $\mathrm{CD}(\mathrm{A})$ Act. $^{92}$ In fact, the Report was worried lest research might undermine the Act.

We consider that if it should be deemed necessary or desirable that further experiments should be conducted, they should be commenced on the clear understanding that the investigation is undertaken entirely in the interests of science, and without any reference to the measures proper to be adopted for the extinction of the disease. ${ }^{93}$

Very significant was the evidence of John M'Fadyean, who was then emerging as Britain's leading veterinary authority in the new science of bacteriology. The following exchange took place when he was questioned by G. T. Brown.

Brown: You think, in reference to the possible discovery of the organism of pleuropneumonia, it would be advantageous to have experiments set on foot?

M'FADYEAN: No, I do not see that more than an indirect interest might attach to it.

${ }^{87}$ Veterinarian, 1879, 52: 351 . Rutherford and his allies dismissed these recommendations as mere laboratory findings and insignificant when compared to farmers' experience with inoculation in herds at home and abroad.

${ }^{88}$ Vet. J., 1879, 9: 14, 410.

89 T. Walley, 'Thrashing out the pleuro question', ibid., 1889, 37: 280-5.

90 Ibid., 1887, 24: 33, 86, 197; ibid., 25: 209, 380, 415-36.

91 Report of the Departmental Committee appointed to inquire into Pleuropneumonia and Tuberculosis in the United Kingdom, PP, 1888, Cd. 5461, XXXII, p. 267.

92 See the editorial in J. comp. Path. Therap., 1888, 1:234, 276. In fact, new Pleuropneumonia Orders were passed in 1888 .

93 Departmental Committee, op. cit., note 91 above, p. 64. 


\section{Germ theories and British veterinary medicine}

No great benefit would result from a knowledge of the specific organism of pleuropneumonia if inoculation cannot be used as a means of eradicating the disease. BROWN: If you got rid of the disease you would not care about the organism? M'FADYEAN: Well, as a matter of pathological curiosity I should like to possess as many specific organisms as possible.

BROWN: But on no other ground?

M'FADYEAN: No. ${ }^{94}$

In 1888 , therefore, even a committed bacteriologist like M'Fadyean was interested only in the organism of pleuropneunomia as a "pathological curiosity". Once again veterinary bacteriology was not being neglected, it was being avoided.

From the late 1870 s veterinary publications, especially Fleming's Veterinary Journal, had kept their readers up-to-date about germ theories and related matters in medical pathology. ${ }^{95}$ Germ theories and their implications were also regularly discussed at meetings of veterinary medical associations. ${ }^{96}$ There was general support for germ theories, which were seen to reinforce importation theory and the desirability of veterinary legislation. ${ }^{97}$ Firm policing measures based on contagion were contrasted disparagingly with the earlier, pre-legislation, "something-in-the-air" ideas, which had allowed weak or non-existent veterinary policing and left Britain open to epizootics. Many veterinarians found no intellectual difficulty in accepting the role of bacteria in disease, as they were parasitic and therefore analogous to the entozoal and fungal diseases which were common in veterinary medicine. ${ }^{98}$

While generally accepting germ theories, veterinarians did not adopt the practices that followed. The élite, as argued above, consciously avoided fostering such work. Amongst the rank and file, few veterinarians would have had the knowledge, opportunity or inclination to take up experimental studies. It should also be remembered that anti-vivisection sentiment was strong in the profession and the vivisection law was more restrictive for veterinarian research than for medical. ${ }^{99}$ Veterinarians had little interest in the greatest of all "germ practices"-antiseptic surgery. Despite having to deal with wounds which were produced and had to heal in

94 Ibid., p. 449 (paras 4996-8).

${ }^{95}$ George Fleming, the editor of the Veterinary Journal, was a supporter of germ theory and an authority on actinomycosis and tuberculosis. His journal's contents and editorial policy, supporting germ theory and reporting bacteriology, were markedly different from those of its rival The Veterinarian. In 1877 there was an extended discussion of Koch's work on anthrax. See: Vet. J., 1877, 4: 118, 349, 451.

${ }_{96}$ In 1878, for example, Thomas Greaves of Manchester spoke on 'Germs' to the Liverpool, Yorkshire, Central and Midland Counties Veterinary Medical Associations: Vet. J., 1878, 6: 53, 366; ibid., 7: 52, 350; ibid., 1879, 9: 1-7.

${ }^{97} \mathrm{G}$. Fleming, Veterinary sanitary science and police, London, 1875, passim.

98 T. S. Cobbold, 'Address at opening of RVC, 1879-80 session', Veterinarian, 1879, 52: 761. Also see: G. T. Brown, 'Animal parasites', International Congress on Hygiene and Demography, London, 1891. The link between "worm theories" and germ theories has been neglected by historians.

${ }_{99}$ H. E. Carter, 'The veterinary profession and the RSPCA: the first 50 years', Vet. Hist., 1989-90, 6(2): 68-70. The three veterinarians who gave evidence to the 1875 Royal Commission on Vivisection were not enthusiastic about the practice. The 1876 Cruelty to Animals Act specified that veterinary experiments could be performed only "under anaesthetic and with a view to the advancement of veterinary science", that is, not for physiological demonstration. Report of the Royal Commission on the Practice of Subjecting Live Animals to Experiments for Scientific Purposes, 1876, C.1397, p. 1. Matters had changed slightly by the 1880s. See G. Fleming, 'Vivisection and the diseases of animals', Nineteenth Cent., 1882, 11: 468-78. 


\section{Michael Worboys}

the most insanitary conditions, it was reported that very few animal wounds ever became septic. ${ }^{100}$ Antiseptic techniques were covered in textbooks and lectures in the 1880 s and 1890 s, but only in relation to dressings and as a means of securing cleanliness. Problems of more interest in veterinary operations were said to be those of tethering the animal, not losing instruments, and finding a soft place for the animal to lie, such as "a dung-heap covered by straw". 101

While veterinarians selectively absorbed ideas about germs, an increasing number of medical researchers were busily developing new techniques for studying the role of germs in animal diseases. The most famous was, and is, Koch's work on anthrax, published in $1876 .{ }^{102} \mathrm{~A}$ year earlier, following researches carried out for the Medical Department of the Privy Council, Klein had reported finding the "Mycelium" responsible for sheep pox, which "caused much sensation in scientific circles". 103 However, within months he had to retract, when Charles Creighton found that the "mycelial growth" was only "some albuminous or kindred material". 104 In 1876 and 1877, Klein, perhaps eager to become the British Koch, reported that swine fever in pigs was caused by a bacillus; indeed, he published a description of the organism several years later. ${ }^{105}$ Again the work was flawed. Whether we think Klein was unlucky or untalented does not really matter: veterinarians used his "errors" both to criticize experimental researches and to defend animal diseases from the encroachments of medical experts. The Veterinarian, edited by Simonds and Brown, was very severe on Klein and the doctors, and the rival Veterinary Journal had to defend its publication of Klein's work, saying that those "who exalt over such mistakes as those of Klein ... are likely to drive us back to the age of farriery". 106

From the late 1870 s some veterinarians and medical practitioners agreed that tuberculosis in humans and bovines was the same disease and inter-communicable. Thus, Koch's identification of the tubercle bacillus in 1882 was not unexpected in the veterinary context. That tuberculosis was an infectious disease was already widely

${ }^{100}$ In 1877 one veterinarian wrote of antisepsis passing "almost into disuse": Vet. J., 1877, 5: 9. Also see: ibid., 1879, 9: 37, 122; Veterinarian, 1879, 52: 376. Antisepsis was regarded as a technique of wound dressing, not an operative procedure. It should be noted that relatively few veterinary operations were performed at this time.

${ }^{101}$ G. Fleming, A textbook of operative veterinary surgery, London, Baillière, Tindall \& Cox, 1884, pp. 4-8. Professor McQueen's lectures at the RVC in the 1890s did discuss the need for antiseptic precautions as well as antiseptic dressings, although the emphasis was still on the latter. Lecture Notes, H. P. Standing (1894) and W. N. Thompson, no date (?1894) Historical Collection, RVC, London.

${ }_{102}$ T. D. Brock, Robert Koch: a life in medicine and bacteriology, Berlin, Springer, 1988, pp. $27-37$.

${ }^{103}$ E. Klein, 'Research on smallpox of sheep', Phil. Trans. R. Soc. Lond., 1875, 165: 215-50.

104 Idem, 'Note on the Mycelium described in my paper on Smallpox of sheep', Proc. R. Soc. London., B, 1876-7, 25: 259-60.

105 Idem, 'Enteric or typhoid fever of the pig', Annual Report of the Medical Officer of Health for 1876, London, HMSO, 1877; idem, 'Infectious pneumo-enteritis in the pig', Annual Report of the Medical Officer of Health for 1877, London, HMSO, 1878; idem, 'The bacteria of swine plague', J. Physiol., 1884, 5: 1-13. This work was disputed by Pasteur. See: L. Pasteur, 'Sur le rouget, ou mal rouges des porcs', C. $r$. Acad. Sci., 1882, 95: 1120-1; 'La vaccination du rouget des porcs a l'aide virus mortel attenué de cette maladie', ibid., 1883, 97: 1163-9.

${ }^{106}$ [G. Fleming], 'The part played by minute organisms in disease', Vet. J., 1877, 4: 118-20. On Simonds's attitude to experimental investigations see Smith, op. cit., note 25 above. Smith's reliability has been questioned, although not specifically his claims about Simonds and experimental enquiry. I. Pattison, 'Major-General Sir Frederick Smith and James Beart Simonds: "A veterinarian destroyed"', Vet. Rec., 1984, 114: 657-8. 
discussed by British veterinarians and was the subject of reports by European veterinary scientists. ${ }^{107}$ Such researches were not developed by British veterinarians, who instead called for tuberculosis to be scheduled under the $\operatorname{CD}(\mathrm{A})$ Act and to be stamped out. They found allies amongst Medical Officers of Health, who expressed fears about the health hazards of diseased meat and contaminated milk. Indeed, it would be in connection with tuberculosis that veterinary bacteriology took off in Britain in the 1890 s, but in the 1880 s investigations were pursued only by medical men, with the exception of M'Fadyean, who was, significantly, probably the only veterinarian in Britain with a medical degree. ${ }^{108}$

By the mid-1880s, the rising tide of bacteriology could no longer be resisted by Britain's veterinary élite. The Veterinary Department first undertook experimental investigations in 1886, some twenty years after the studies of the Royal Commission on the Cattle Plague and the start of the Medical Department's experimental researches. However, the first investigations made were not aimed to advance veterinary knowledge per se, but to defend veterinary science against the encroachments of medical investigators.

As germ theories became accepted, there was growing medical and public interest in the channels and agencies of disease transmission. Flies, in particular, were implicated, but there was also concern about farm and domestic animals as sources and carriers of human infectious diseases. ${ }^{109}$ For example, typhoid fever was spread via cow's milk, and diphtheria by cats. ${ }^{110}$ The specific context of the Veterinary Department's move into experimental research were claims, made by Klein and Power of the Medical Department, to have discovered a new cattle disease-the so-called Hendon disease. ${ }^{11}$

Following a well-publicized investigation, Klein claimed that the Hendon disease was a form of scarlet fever, previously unrecognized by veterinarians, which could in certain conditions be communicated to humans. The veterinary profession was outraged by this apparent nonsense, another attack on their competence. To defend its honour the Veterinary Department employed E. M. Crookshank, of King's College Hospital, London, to make fresh investigations in Hendon. ${ }^{12}$ The choice of Crookshank was significant, for he and Klein were metropolitan rivals for the

\footnotetext{
${ }^{107}$ T. Walley, 'Tubercle', Vet. J., 1878, 7: 184; G. Fleming, 'Tuberculosis from a sanitary and veterinary viewpoint', ibid., 1880, 10: 303, and ibid., 11: 4, 74-95.

${ }_{108}$ Tuberculosis was investigated by the Medical Department of the Local Government Board. Also see: G. Sims Woodhead and J. M'Fadyean; 'Tubercle in the dairy', Br. med. J., 1887, ii: 673-4.

${ }^{109}$ G. Sims Woodhead and J. M'Fadyean, 'Notes on the microparasites of domestic animals', Veterinarian, 1886, 59: 591. On milk see: Br. med. J., 1883, ii: 591, 744.

110 ibid., 1879, i: 48, 148; ibid., 1890, i: 1081, 1259; and G. Turner, 'Report on the experience of diphtheria, especially its relations to lower animals', Sixteenth Annual Report of Local Government Board, Supplement: Report of the Medical Officer for 1886, PP, 1887, C.5171, XXXVI, p. 619, which reported evidence of diphtheria in pigeons, chickens, swine, horses, and cats.

${ }_{111}$ L. G. Wilson, 'The historical riddle of milk-borne scarlet fever', Bull. Hist. Med., 1986, 60: 321-42.

112 This episode changed Crookshank's career. At King's he had a prestigious appointment working with Lister and Watson Cheyne, running London's largest bacteriology course. His researches on Hendon disease led him to inquire into the nature of cowpox and vaccination and eventually to become a medical outcast as he became a leading anti-vaccinationist. E. M. Crookshank, The history and pathology of vaccination, vol. 1, London, H. K. Lewis, 1889. Crookshank came to term his alternative to vaccination "the stamping out system".
} 


\section{Michael Worboys}

leadership of the British school of bacteriology. Crookshank quickly reported that Hendon disease was in fact cowpox, a finding which Klein never contested. The veterinary press applauded his work and its vindication of veterinary expertise: one report stated that "no more absolute refutation of an error has ever been made". 113 An indication of what was at stake is, that although the disease had long disappeared, the Veterinary Department rushed out a special report in the summer of 1888 , rather than wait and include it in the annual report. ${ }^{114}$

Crookshank was retained as a bacteriologist to the Veterinary Department, although he continued to work only on non-scheduled diseases like actinomycosis and tuberculosis. ${ }^{15}$ In 1888 he began giving lectures on bacteriology at the RVC, assisted by Horsley and Watson Cheyne; in the same year laboratory work in bacteriology was introduced. ${ }^{116}$ While bacteriology became an integral part of veterinary medicine, the élite still considered experimental investigations to be a potential threat to the stamping-out policies. Thus, as late as 1888 , in referring to swine fever, G. T. Brown observed that the minute character of diseases was of scientific interest, but "from the sanitary police point of view it is of not much consequence". 117

For twenty years or so after the cattle-plague crisis of $1865-66$, British veterinary medicine created and sustained a distinct conception of pathology, concerned with whole animals, herds, and the livestock economy. This construction of livestock diseases was made in terms of importation theories of disease and was linked to the policy of stamping-out, a product of the peculiarities of British geography, the interests of the British veterinary élite, and crypto-protectionism. Having been converted to contagionism by their experience of the cattle plague and its aftermath, veterinarians welcomed the further support to these views, and their legislative embodiments, that germ theories of disease gave from the 1870 s. The importation theory was in some ways conceptually analogous to germ theories of disease. Both explained disease in terms of pathological agents which invaded an otherwise healthy system. These agents multiplied and spread, eventually disrupting or destroying the system's normal functioning. In human infections the agents were "germs", the system was the body, and the process was infection. With epizootics, the agents were diseased cattle, the system was the livestock economy, and the process was importation.

While the importation and germ theories of disease were congruent and mutually supportive, the practices derived from and associated with the two were quite distinct.

113 Vet. Rec., 1888-89, 1: 301. M'Fadyean referred to the Power and Klein work, and another claim about diphtheria in animals, as "absurd". J. comp. Path. Therap., 1888, 1: 239.

${ }^{114}$ G. T. Brown, Report on Eruptive Diseases of the teats and udder in cows in relation to Scarlet Fever in Man, PP, 1888, C.5481, XXXII, p. 1.

115 Annual Report of the Agricultural Department of the Privy Council on Contagious Diseases, [etc.] for 1888, PP, 1889, C.5679, XXVII, p. 3 (Appendix).

116 Veterinarian, 1888, 61: 713.

117 Annual Report of the Agricultural Department of the Privy Council on Contagious Diseases, [etc.] for 1887 , PP, 1888, C.5340, XXXIII, p. 7. Experiments were abandoned at the RVC because of the cost and its lack of a vivisection licence. 
Those linked to importation theory took British veterinary medicine on a trajectory quite distinct from that developing in human medicine at the same time. Indeed, there were conflicts when the two practices met. Elite veterinarians were particularly hostile to experimental pathology, which was increasingly becoming the symbol of the new scientific medicine. They feared that experimental work might encourage what they saw as meliorist control policies, like inoculation or treatments. Thus while germ theories of disease were taken up by veterinarians, germ practices were not. ${ }^{118}$ More generally, the veterinary preference for stamping-out and legislative control had consequences for the identity of the professional and its relations with the medical profession. Veterinary surgeons came to see professional legitimization principally in terms of their association with the state, not with science.

The alternative trajectory of veterinary medical development identified here with regard to epizootic diseases is not entirely original. It was recognized, perhaps inadvertently, a quarter of a century ago in a centenary history of animal health in Britain. ${ }^{119}$ In an equivalent volume on human health and medicine there would be an obligatory list of the discoverers of major pathogens; in this review of veterinary medicine there is a list, running to six pages, of 'Acts, Orders and Regulations'.

\footnotetext{
${ }^{118}$ The absence of veterinary researchers in Britain at the turn of the century is discussed in P. F. Cranefield, Science and empire: East Coast fever in Rhodesia and the Transvaal, Cambridge University Press, 1991, pp. 60-86.

${ }^{119}$ MAFF, op. cit., note 8 above, Appendix.
} 